\title{
Identification of Skills Needed for Central Areas of Green and Low-Carbon Economy, for the Needs of Labor Market, in Finland
}

\author{
1 Sykli Environmental School of Finland, FINLAND \\ ${ }^{2}$ University of Gälle, SWEDEN \\ ${ }^{3}$ Häme University of Applied Sciences, FINLAND \\ *Corresponding Author: tove.holm@sykli.fi
}

Tove Holm ${ }^{1,2 *}$, Pauli Vennervirta ${ }^{1}$, Tapani Pöykkö ${ }^{3}$, Eeva Hämeenoja ${ }^{1}$, Nina Teirasvuo ${ }^{1}$

Citation: Holm, T., Vennervirta, P., Pöykkö, T., Hämeenoja, E. and Teirasvuo, N. (2017) Identification of Skills Needed for Central Areas of Green and Low-Carbon Economy, for the Needs of Labor Market, in Finland, European Journal of Sustainable Development Research, 1:1 (2017), 5.

doi: http://dx.doi.org/10.20897/ejosdr.201705

Received: June 20, 2016; Accepted: September 12, 2016; Published: January 17, 2017

\begin{abstract}
EU has set sustainable growth as a goal for 2020, by which a transition to a more resource efficient greener and competitive economy should be achieved. This requires new skills in business life. We have studied how vocational education and training and higher education may serve as a promoter of a green and low-carbon economy in Finland. Based on results from interviews of companies three main areas were chosen. These areas were decentralized renewable energy production, use of organic by-products and promotion of energy efficiency in properties. Education in vocational education and training and universities of applied sciences, for the selected areas, was mapped in 2014-15. The results were presented on workshops, where knowledge supply chains for a green economy on the selected areas were developed. If was found that cooperation between different fields and levels of education is important, as the new skills often emerge at the interfaces.
\end{abstract}

Keywords: Baltic Sea region, bioeconomy, Finland, higher education, vocational education and training

\section{INTRODUCTION}

In the Global Action Program for Education for Sustainable Development post 2014 one suggested action for technical and vocational education and training, is to respond to the need for greater clarity in defining the skills and competencies needed for green jobs (UNESCO, 2014).

Business that promotes green growth should be enhanced much more than it is currently. EU has set sustainable growth as a goal for 2020, by which time the transition to a more resource efficient, greener and competitive economy should be achieved. This requires building a more competitive low-carbon economy that makes efficient, sustainable use of resources, protecting the environment, reducing emissions and preventing biodiversity loss, capitalising on Europe's leadership in developing new green technologies and production methods, harnessing EU-scale networks to give businesses (especially small manufacturing firms) an additional competitive advantage, improving the business environment, in particular for SMEs and helping consumers make well-informed choices. This requires new skills in business life (European Commission, 2011). The European Commission estimates that 20 million jobs could be created by 2020 in green economy. The eco-industries, it recognizes, also offer great opportunities for young people. EU governments are being encouraged to exploit this potential by re-focusing their training efforts and including green employment as a key target of their National Job Plans. (Lambert 2012). In Finland, green economy is a key action in the Strategic programme of the Finnish Government. (Finnish Government Publications, 2015) 
The transition to green economy produces various benefits, but, simultaneously the transition is a long-term challenge and requires actions and significant technological, behavioural and system changes at all levels of society, including citizens, private companies, public sector and. decision-makers (Antikainen et al. 2015). A key challenge in transition to a green economy is capacity building, which means not only increasing the skills of the existing workforce, but also increasing the numbers of skilled people working in the sector because both are needed to drive new businesses and to exploit the potential markets. The European Centre for the Development of Vocational Training has studied the skills needed for a green economy in Europe. They have identified a need to integrate environmental expertise into the existing professions (CEDEFOP, 2010). The skills needed for green economy, for the needs of labor market, in Finland, has been studied for universities (for example Holm et al., 2015; Klimova et al., 2016 and Takala \& Korhonen-Yrjänheikki, 2015), but skills needed for vocational education and training and universities of applied sciences has not been studied.

Sykli Environmental School of Finland is a national specialist vocational college. The mission of Sykli is to reinforce environmental knowledge and improve the customers' operations in line with sustainable development objectives (Sykli Environmental School of Finland, 2015). Skills needed in the environmental fields in Finland were studied by Sykli Environmental School of Finland in the Environmental Experts in 2025 foresight project in 20092012. One key result of that study was that, in the future environmental experts and environmental know-how is needed in all sectors, not just in traditional environmental sectors. Application of environmental knowledge is needed in different fields, for example, management of environmental impacts of a field and know-how in sustainable solutions (Lundgren, 2012).

The aim of this research was to study the gap concerning identification of skills needed for central areas of green economy, for the needs of labor market, in Finland. Provided education corresponding to the skills needed for the selected areas was studied in education that educate professionals for the labor market. The Environmental Program of the United Nations (UNEP) has defined the green economy as "one that results in improved human well-being and social equity, while significantly reducing environmental risks and ecological scarcities. It is low carbon, resource efficient and socially inclusive" (UNEP, 2011b). Thus, UNEP's definition has been cited in a number of more recent reports, including by the UNEMG and the OECD, in this paper the definition if followed. Curricula in both undergraduate and continuing education were studied in vocational education and training, vocational colleges and universities of applied sciences. In addition, knowledge supply chains, (for example from planning to sale, maintenance and after-sales), for a green economy on the selected areas, were developed. Trade associations or associations of selected industries and companies were also involved as these have a broader vision for the development and the development needs of the sector. Also, companies were involved, as examples. The aim was to find out how well current education answers to the identified skills needed and which are the main development needs for know-how and education. The goal was that this review would provide a foundation for the development of educations and educators in Finland and to identify possible bottlenecks in the knowledge supply chains, by comparing and analysing the skills needed of different groups.

\section{THREE MAIN AREAS OF SKILLS NEEDED FOR GREEN ECONOMY}

Sykli Environmental School of Finland studied how vocational education and training may serve as a promoter of a green and low-carbon economy in Finland in 2014. According to the latest definition by UNEP green economy is "an alternative to today's dominant economic model, which generates widespread environmental and health risks, encourages wasteful consumption and production, drives ecological and resource scarcities and results in inequality. It is an opportunity to advance both sustainability and social equity as functions of a stable and prosperous financial system within the contours of a finite and fragile planet. It is a pathway towards achieving the 2030 Agenda for Sustainable Development, eradicating poverty while safeguarding the ecological thresholds, which underpin human health, well-being and development" (UNEP, 2016). This means that all sustainability aspects ought to be covered when studying green economy. For this study three central areas of skills needed for green economy were chosen, for limiting the study to fit within the financed project. They were chosen based on a preliminary study of the green economy field and results from interviews. The ones which was chosen to be interviewed were from companies that operated in the environmental business sector, as well as from organizations whose mission was to promote corporate environmental business. The preliminary results were presented at a workshop, organized at a seminar, at which educators from the field participated, where it was discussed if these are the ones that ought to be studied. This methodology was chosen for finding out what the actives in green economy business thought were the most current areas at that point. The following competence areas were selected based on the answers:

1) decentralized renewable energy production,

2) use of organic by-products and

3) promotion of energy efficiency in properties (Annala et al., 2015.). 
The green economy is to uncouple the use of resources from the economic growth. This process is called decoupling, which, at its simplest is reducing the amount of resources such as water or fossil fuels used to produce economic growth and delinking economic development from environmental deterioration (UNEP 2011a). The main activities to enhance green economy are bioeconomy, circular economy and clean tech (for example Kiørboe \& Milios, 2015; Johnsen et al. 2015). The selected competence areas fit these activities. The social aspects for sustainability were therefore not a focus in this study.

\section{FROM SUSTAINABLE DESIGN TO IMPLEMENTATION OF SUSTAINABILITY ASPECTS IN CURRICULA IN VOCATIONAL EDUCATION AND TRAINING, VOCATIONAL COLLEGES AND HIGHER EDUCATION}

Education in vocational education and training and vocational colleges, for the selected areas, was mapped in 2014. It was mapped by looking into what could be found published on the webpages of the education providers. This methodology was chosen to ensure that all educational providers within the field would be included in the results. The results and results from international a corresponding European and international study were presented and discussed in an open workshop, at which interested in the field participated. At the workshop the participants were divided into three groups, according to the competence areas and the following questions where discussed and presented: 1) identify and describe the knowledge supply chains \& which trade unions and groups of actors are associated with the studied competence area; 2 ) what are the skills needs of the different stakeholder groups; 3) how well does current education answer to these skills needs; 4) what and how should know-how and education be developed a) primarily: b) on a long time perspective; and 5) could international examples of education and practices be exploited? It was found that multi-skilled experts that understand different fields at the same time would be obtained if education would provide content and perspectives that complement that specific field of expertise. Cooperation between different fields and levels of education is important, as new skills often emerge at the interfaces. Based on the results a need to review the education conducted in higher education, especially in Finnish universities of applied sciences, was identified, as well as what skills are needed for different fields, especially based on the needs of the labor market (Annala et al., 2015.). The Finnish higher education system consists of two complementary sectors: universities of applied sciences and universities. Universities conduct scientific research and provide instruction and postgraduate education based on it. Universities of applied sciences train professionals in response to labor market needs and conduct research and development which supports instruction and promotes regional development in particular (Ministry of Education and Culture, 2015).

Corresponding education in Finnish universities of applied sciences, for the selected areas, was studied in March- April 2015 (Annala et al., 2015.). It was done by conducting a survey that was filled online. In the survey key skills for the selected areas were investigated. Competencies that contribute to new business and low-carbon solutions were in particular chosen for the study. A call to fill in the survey was sent by e-mail to all education program managers of universities of applied sciences in the Finnish mainland (all expect Åland Islands, which is an Island outside the mainland) in the fields of technology, economics and natural sciences and to some vocational colleges and vocational education and training institutions in the fields, those that had participated in the study conducted in 2014. In addition, the call was distributed by publishing an article about the study in the Journal of Finnish Universities of Applied Sciences in March 2015, by adding a news article about it on the website of Sykli Environmental School of Finland and by sending some e-mails about it to the Finnish Sustainable Developmentforum in higher education network. At this point this methodology was chosen for getting answers from the most interested ones, and especially the opinions of the experts that worked at the educational institutions that provided education within this field, that had been studied the year before. This means, on the other hand that involved in the study had some interest in driving green economy and was therefore self-selecting and excluded those who did not have a concern for sustainability strategies.

Virtually all respondents thought that the need for education in green economy will grow in the future. In particular, it was supposed that the need for education that deals with managing and measuring energy efficiency and energy efficient industrial processes will grow in the future. Each respondent was interested in developing their education and to participate in co-operation with regards to this study.

\section{KNOWLEDGE SUPPLY CHAINS FOR GREEN ECONOMY}

The results from the survey concerning corresponding education in Finnish universities of applied sciences were presented on two workshops in May 2015. The first workshop focused on promotion of energy efficiency in properties and the second on decentralized renewable energy production and use of organic by-products. In the workshops participating representatives from education, companies and trade associations, and one representative 
Companies

\begin{tabular}{|c|c|c|c|c|}
\hline $\begin{array}{l}\text { Designing or } \\
\text { planning }\end{array}$ & Production & Sales & $\begin{array}{c}\text { Installer, } \\
\text { maintenance }\end{array}$ & $\begin{array}{l}\text { After sales } \\
\text { services }\end{array}$ \\
\hline $\begin{array}{l}\text { What kind of know- } \\
\text { how do designers } \\
\text { need? For } \\
\text { example technical } \\
\text { expertise, } \\
\text { customer } \\
\text { knowledge, etc. }\end{array}$ & $\begin{array}{l}\text { What kind of know- } \\
\text { how do producers } \\
\text { of services, } \\
\text { products and } \\
\text { technological } \\
\text { solutions need? }\end{array}$ & $\begin{array}{l}\text { What kind of know- } \\
\text { how do equipment } \\
\text { and solutions } \\
\text { vendors need? }\end{array}$ & $\begin{array}{l}\text { What kind of know- } \\
\text { how do equipment } \\
\text { installers and } \\
\text { maintenance } \\
\text { need? }\end{array}$ & $\begin{array}{l}\text { Which other actors } \\
\text { are connected to } \\
\text { the chain? What } \\
\text { kind of know-how } \\
\text { do they need? }\end{array}$ \\
\hline
\end{tabular}

Trade associations
Universities of Applied Sciences

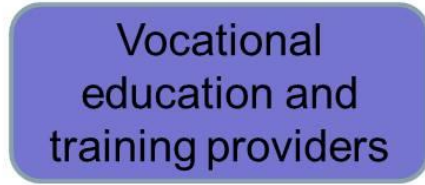




\section{RESULTS AND CONCLUSIONS}

The aim of this research was to study the gap concerning identification of skills needed for central areas of green economy, for the needs of labor market, in Finland. The aim was to find out how well current education answers to the identified skills needed and which are the main development needs for know-how and education. The goal was to identify possible bottlenecks in the knowledge supply chains, by comparing and analysing the skills needed of different groups.

We found that there is a need for additional education at all levels concerning the transition towards green economy, as part of undergraduate and continuing education, for professionals in the field and educators, as follows:

- sales and marketing, namely business know-how expertise,

- profitability calculations,

- life cycle calculation, environmental impact assessment,

- hybrid solutions,

- social media and digitalization, in education (access to material online, and education online), and development of technology (remote tutoring, measurement and monitoring systems and management of them),

- promotion of industrial symbiosis between the actors in various fields, one's waste is another's raw material,

- legislation, regulation and other means of social control,

- user experiences and

- experts in the entire knowledge supply chains, for example, energy efficiency expertise.

The educational system should be modular, from which students could choose studies. The field needs cooperation among universities (researchers), universities of applied sciences, vocational education and training, advisers and business for the design and development of education, as the new expertise often arise at the interfaces. The needed cooperation could be enhanced through joint projects. All institutions should consider their own role; which is my own role in the knowledge supply chain? To enable this actives that enhance green economy ought to come together and establish a cross disciplinary network, that include different stakeholders and educators from different fields and levels of education. The aim of the network ought to be to develop new skills and education corresponding education. Challenges for funding this are that most financers provide funding for specific fields, which this is not. Since we noticed that there was not a common definition for green economy among the ones that participated in this study, it can be assumed that the same goes for financers, which means that the description of the upcoming network and applications for it ought to be very clear. At the upcoming network meetings, it ought to be taken into account that the participants have different views of green economy and what it should focus on.

The reason for applying a variety of methodology for this study like interviews, surveys, finding information on the internet, several workshops and final interviews about the preliminary results among experts, was to do a profound study. We did unfortunately not get an answer of the difference between emphases, neither interpretation of the term because the interpretation varied among all participants. We argue that this indicates that there is a need for defining the principles of green economy.

The aim was also that this study would provide a foundation for the development of educations and educators. The steering group of the project that this study was made in consisted of key persons for developing national curricula in Finland. The steering group thought that the results were broad and useful, which also the ones who were interviewed about the final results answered, why we experience that at least some of the educators found it as a good foundation for development.

The limitations of this study where that the chosen competence areas covered only economic and ecological sustainability aspects, or with other words that the social aspects where not in focus, although all aspects ought to be considered when enhancing a green economy. The reason for the exclusion was that the chosen areas were chosen based on results from interviews with representatives from the green economy business in a preliminary study, where the economic and ecological aspects were emphasized. Since all participants that filled the survey and that participated in the workshops had some interest in driving green economy either by creating enterprises, educating in the field or living on grant aid for research, the ones that are critical and could contribute with aspects from other disciplines and fields of interest are lacking. We did not get results on how the identified skill needs will improve the sustainable outcomes, what sort of time scale and what sort of organisational structures should manage the process, which educators that will include these aspects ought to dig into.

Green economy and related skills needs is a broad area, which is why we consider that future follow-up studies should be more focused, if more detailed and comprehensive results in a certain area is wanted. On the other hand, it has been important to understand the scope of the topic and forming a comprehensive view on the matter, and including all sustainability aspects, the economic, ecological and social, which was also highlighted in the conducted 
interviews of the final results. For the educational point of view, the field of green economy still is quite dizzy, which limits the possibilities to specify the exact skills needed. The overall articulation of green economy as well as bioeconomy and circular economy ought to be improved to meet needs of research and education. The more exact theory to cover the green economy is needed.

\section{FUTURE DIRECTIONS}

There is scope to conduct further research on knowledge supply chains for bioeconomy and bioenergy in the Baltic Sea Region. We would like to study how bioeconomy and bioenergy use is enhanced locally in the entire supply chain from production to consumers, and aim at identifying which are the bottlenecks, concerning the link between innovators, production, industries, companies, farms, consumers, educators are research?

According to the EU Strategy for the Baltic Sea Region the region aims at creating an energetic innovation environment. Because the region is being composed of small countries and innovation environments of different levels of development, it is crucial to strengthen transnational co-operation. This requires priority on a sector in which the region is particularly strong, which is for example bioeconomy and bioenergy, for which a map of clusters could be developed. The different countries have various things to offer in terms of knowledge and could therefore complement each other.

To limit the wide scope of green economy and to focus on key questions raised in the study we have chosen bioeconomy since it is a priority area in the Baltic Sea Region due to high priority of bioeconomy (European Commission, 2012a) and later bioeconomy as part of circular economy (European Commission 2015) in EU. Bioeconomy offers many opportunities - for economic, social and environmental sustainable development. For example, bioeconomy offers many new business and job creation opportunities; it offers many new development opportunities for rural areas; and it offers an abundance of opportunities to grow primary industries while at the same time preservation of the environment, on land as well as in the sea, is emphasized. The relationship between bioeconomy and green economy is shortly discussed by Antikainen et al. 2015. According to them bioeconomy can be seen as a part of green economy, but they are not synonyms: a bioeconomy focuses on products and services based on renewable resources whereas green economy also encompasses aspects related to broader environmental and socio-economic sustainability, also covering the use of non-renewable materials (Antikainen et. all, 2015). The bioeconomy is part of the solutions towards sustainable society.

Although the concept of bioeconomy has been pursued since 2007 by the EU, as a part of the new EU Framework Programme for Research \& Innovation Horizon 2020 and previous programs, it is evident that the understanding of the concept varies significantly. This can be seen in the Nordic region; some Nordic countries (and actors) have adopted the term "bioeconomy", whereas other regions are only starting to become familiar with the term (Teräs et al. 2014). In this study neither the variety in the interpretation of the term for bioeconomy, or the difference between emphasis was studied why we argue that when studying bioeconomy there is a need for defining the principles that the participating stakeholders agree on.

Finland holds the Presidency of the Nordic Council of Ministers in 2016. The main themes of the Finnish Presidency are water, nature and people. The objective is to generate interest in Nordic cooperation and make it even more relevant, including to business and civil society (Nordic Council of Ministers, 2015). Water and bioeconomy are interlinked. The constraints from growing water scarcity may influence bioeconomic growth in a number of regions globally. However, the Nordic counties have water in abundance, giving many advantages in the transition to bioeconomy. Biomass is available in large quantities in the Nordic countries, in the large boreal forests. However, the abundance of water and biomass cannot be taken for granted as pressures increase, but they are clearly advantages in launching the large-scale bioeconomy. The world economy is under pressure for greater, more efficient and more sustainable use of natural resources to meet complementary and competing objectives in the food, water and energy sectors. Interactions between these three sectors are increasingly evident in the pursuit of the bioeconomy - a concept that encompasses economic growth driven by the development of renewable biological resources and biotechnologies to produce sustainable products, employment and income (Rosegrant et al, 2013).

The bioeconomy (or biobased society) is today strongly pushed by many important actors in Europe, both because of the renewable resource base of such a society and because of the perceived commercial opportunities that it entails for industry. It reduces the dependence on fossil fuels and is key to combating climate change and the depletion of natural resources. However, the large-scale shift from fossil to renewable feedstocks in industry requires considerable changes and innovation not only in terms of technical processes and products but also in terms of e.g. value chains, logistics, policies, etc. The transition requires a different set of skills in the workforce skills adapted to achieving and managing the new situation.

The bioeconomy implies a shift from feedstocks that are relatively concentrated, pure, stable in properties and appear in large amounts at its sources, to feedstocks that are distributed, moist and highly variable in their 
properties depending on season and source. Further, as fund-type resources will be increasingly exploited, appropriate management of the productive ecosystems will be critical. Furthermore, a more diverse set of products from biorefinery-type facilities and corresponding shifts in markets is anticipated. The shift in feedstocks and technologies in themselves therefore imply large changes that demand new skills. Further, in order to transcend smoothly and quickly into this new situation, important actors need to be equipped with skills for the transition itself, sometimes referred to as transition leadership. This involves, among other things, the ability to plan for and carry out a change in collaboration with other relevant actors.

The bioeconomy thus encompasses all kinds of production based on biobased resources, including the further development and use of innovations and technologies related to such materials. It also promotes systemic change from using non-renewable resources to renewables. It can be said to reform the social system (Luoma et al., 2011). Bioeconomy is often linked to rural areas (see Albrecht and Ettling, 2014). However, bioeconomy is not a step back to the agricultural society as is sometimes suggested. On the contrary, with strong connection to advanced technology, the well-being created in the bioeconomy is based on the smart and responsible use of renewable resources. The transition to the bioeconomy calls for multidimensional skills including technology, business and natural resources, but also those needed in administration at all levels, legislation and regulation.

Bioeconomy cooperation must be geared towards cross-sectoral activities that create innovative solutions and improve competitiveness to give momentum to businesses that are successful on the international market. Cities and subregions must be harnessed to this cooperation, and strong links must be forged with international networks. Promotion of bioeconomy growth must also have a role in land use and urban planning.

Education has an important role in terms of providing the new set of skills to the graduating professionals and also in helping industry modernize the skills of the already employed. On the other hand, industry also has important input in terms of the perceived gaps in their workforce and in terms of the reality that they operate in. Also, many companies have schemes for continuing education. This needed shift in the skills of the workforce must therefore be managed as a close collaboration between researchers, educators, industry and other actors, see for example European Commission (2012b).

Efforts ought to be made to enhance bioeconomy by providing meeting places and platforms for stakeholder engagement and cooperation; and grow the bioeconomy by support development of concrete and visible cooperation activities (European Commission, 2009). Further, most research on the idea of the bioeconomy focuses on technological solutions, not the actual society in which they will be released. Part of the task of this project will be to ensure that students who want to work in this new and growing field will have the full skillset required to implement these innovations in society. For conducting research in themes related to bioeconomy, strong experience of interdisciplinary applied research is needed, taking into consideration all sustainability aspects, both the ecological, economic and social, and utilization of research networks.

\section{ACKNOWLEDGMENTS}

The financial support received from the European Social Fund by the Centre for Economic Development, Transport and the Environment in Uusimaa, Finland is gratefully acknowledged. We would also like to thank all presenters at the workshops of the two projects from sustainable design to sustainable implementation: knowledge supply chains for a green economy, conducted in 2015 and how vocational education and training may serve as a promoter of a green and low-carbon economy, conducted in 2014. All that answered the survey about corresponding education for the selected areas are also gratefully appreciated. The contribution of all that were interviewed about the final results is also gratefully acknowledged. Finally, we would like to thank the participants of the steering group of the projects in which the results were obtained, and all colleagues at Sykli Environmental School of Finland and HAMK, University of applied Sciences, which worked in and for these projects.

\section{REFERENCES}

Albrecht, K. and Ettling, S. (2014) Bioeconomy strategies across the globe. Rural, 21(3), pp. 10-13.

Annala, K., Holm, T. and Hämeenoja, E. (2015). Vihreää liiketoimintaa edistävää osaamista koulutusasteiden rajat ylittävällä yhteistyöllä [Enhancement of know-how that promotes green business by cooperation over education levels]. Journal of Finnish Universities of Applied Sciences, 1, 2015.

CEDEFOP (2010). Skills for green jobs, European synthesis report. Publications Office of the European Union, Luxembourg.

European Commission (2009). EU Strategy for the Baltic Sea Region. European Commission, Brussels.

European Commission (2011). A resource-efficient Europe - Flagship initiative under the Europe 2020 Strategy. European Commission, Brussels. 
European Commission (2012a). Innovating for Sustainable Growth - A Bioeconomy for Europe. European Commission, Luxenburg.

European Commission (2012b). New Skills for a European Bioeconomy, Conference Report. European Commission. [online] Available at: http://ec.europa.eu/research/bioeconomy/pdf/report-designed2_en.pdf [Accessed 20 June 2016].

European Commission (2015). Closing the loop - An EU action plan for the Circular Economy. European Commission, Brussels.

Finnish bioeconomy strategy, Sustainable growth from bioeconomy (2014). Publications of The Ministry of Employment and the Economy, Finland.

Finnish Government Publications (2015). Finland, a land of solutions. Strategic Programme of Prime Minister Juha Sipilä’s Government 29 May 2015. Government Publications 12/2015. Edita Prima, Helsinki.

Holm, T., Sammalisto, K., Grindsted, T., S., Vuorisalo, T. (2015). Process framework for identifying sustainability aspects in university curricula and integrating education for sustainable development. Journal of Cleaner Production, 106, pp. 164-174.

Johnsen, I.H.G. (ed.), A. Berlina, G. Lindberg, N. Mikkola, L. Smed Olsen and J. Teräs (2015). The potential of industrial symbiosis as a key driver of green growth in Nordic regions. Nordregio Report 2015:1. Nordregio, Stockholm.

Klimova, A., Rondeau, E., Andersso, K., Porras, J., Rybin, A. and Zaslavsky, A. (2016). An international Master's program in green ICT as a contribution to sustainable development. Journal of Cleaner Production, 135, pp. 223239.

Kiørboe, K. and Milios, L. (2015). Circular economy and bioeconomy in the Nordic region, [online] Available at: http://www.norden.org/en/news-and-events/articles/circular-economy-and-bioeconomy-in-the-nordicregion [Accessed 20 June 2016].

Lundgren, K. (ed.) (2012). Ympäristöosaajat 2025, tulevaisunden osaamistarpeet ympäristöaloilla. Environmental Experts in 2025, the future skills needs of environmental fields]. Savion kirjapaino, Kerava.

Luoma, P., Vanhanen, J. and Tommila, P. (2011). Distributed Bio-Based Economy - Driving Sustainable Growth. Sitra, Finnish Innovation Fund.

Ministry of Education and Culture (2015). University of applied sciences' education in Finland, [online] Available at: http://www.minedu.fi/OPM/Koulutus/ammattikorkeakoulutus/?lang=en [Accessed 27 May 2016].

Nordic Council of Ministers (2015). Water, nature and people: Programme for the Finnish Presidency of the Nordic Council of Ministers 2016. Copenhagen: Nordisk Ministerråd.

Rosegrant, W.M., Ringler, C., Zhu, T., Tokgoz, S. and Bhandary, P. (2013). Water and food in the bioeconomy: Challenges and opportunities for development. Agricultural Economics, 00(2013), pp. 1-12.

Sykli Environmental School of Finland (2015). SYKLI - creating environmental experts, [online] Available at: http://www.sykli.fi/en [Accessed 27 May 2016].

Takala, A., Korhonen-Yrjänheikki, K. (2015). Are Finns walking the talk? : Examining the national collaboration process on engineering education for sustainable development five years later. In: $7^{\text {th }}$ International Conference on Engineering Education for Sustainable Development. [online] Vancouver, B.C. Available at: https://open.library.ubc.ca/cIRcle/collections/52657/items/1.0064702 [Accessed 21 August 2016].

Teräs, J., Lindberg, G., Johnsen, I.H.G., Perjo, L. and Giacometti, A. (2014). Bioeconomy in the Nordic region: Regional case studies. Nordregio Working Paper, 2014:4.

UNEP (2011a). Decoupling natural resource use and environmental impacts from economic growth, $A$ Report of the Working Group on Decoupling to the International Resource Panel. Fischer-Kowalski, M., Swilling, M., von Weizsäcker, E.U., Ren, Y., Moriguchi, Y., Crane, W., Krausmann, F., Eisenmenger, N., Giljum, S., Hennicke, P., Romero Lankao, P., Siriban Manalang, A., Sewerin, S.

UNEP (2011b). Towards a Green Economy: Pathways to Sustainable Development and Poverty Eradication - A Synthesis for Policy Makers, [online] Available at:www.unep.org/greeneconomy [Accessed 20 June 2016].

UNEP (2016). [online] Available at: http://web.unep.org/greeneconomy/what-inclusive-green-economy [Accessed 21 August 2016].

UNESCO (2014). UNESCO roadmap for implementing the Global Action Programme on Education for Sustainable Development. Paris: UNESCO. 